\title{
Serum Osteocalcin Regulation in Protein-Energy Malnourished Children
}

\author{
BIRAM NDIAYE, DANIEL LEMONNIER, MOHAMMADOU G. SALL, CLAUDINE PRUDHON, \\ BABOU DIAHAM, FATIHA ZEGHOUD, HUGUETTE GUILLOZO, NADINA LEITE, AND
} SALIMATA WADE

INSERM, Faculté de Médecine Xavier Bichat BP 416, 75870 Paris cédex 18, France [B.N., D.L., C.P.], Faculté de Médecine et Faculté des Sciences, UCAD, Dakar, Senegal [M.G.S., B.D., N.L., S.W.], and CNRS URA 583 Hôpital Necker, 75015 Paris, France[F.Z., H.G.] \begin{abstract}
To evaluate bone turnover changes occurring during protein-
energy malnutrition, serum osteocalcin, a marker of bone formation, has been studied in healthy control, stunted, and severely malnourished (kwashiorkor and marasmus) Senegalese children. Serum osteocalcin levels were dramatically reduced in stunted, kwashiorkor, and marasmic children compared with control children. In addition serum osteocalcin levels of control children living in Senegal were lower $(-46 \%)$ than those of African children living in France. Interestingly, serum osteocalcin level was not related to its major known regulators $(1 \alpha, 25$ dihydroxycholecalciferol, 25-hydroxycholecalciferol, and PTH) nor to stunting, but was related to serum transthyretin and thyroid hormones concentrations. These data suggest that serum osteocalcin level is related to protein-energy status and that bone formation was affected in apparently healthy and in malnourished
\end{abstract}

Senegalese children. Serum osteocalcin could be a potent tool in the study of the alterations of bone formation in malnutrition. (Pediatr Res 37: 606-610, 1995)
Abbreviations
1,25(OH)2D, $1 \alpha, 25$-dihydroxycholecalciferol
25(OH)D, 25-hydroxycholecalciferol
CD, control children living in Dakar
CP, control children living in Paris
iPTH, immunoreactive PTH
$\mathbf{K}$, kwashiorkor children
M, marasmic children
MS, moderately stunted children
PEM, protein-energy malnutrition
SS, severely stunted children

PEM is a great problem which concerns about half the world's children. However, contrary to other aspects of PEM, bone metabolism has received little attention. Most of the studies on bone are from the last decades and were hindered by the lack of appropriate tools for investigation of bone turnover. Previous studies based on radiography or ash weights have suggested an increase of bone resorption (1), whereas recently, Branca et al. (2), using urinary pyridinoline and deoxypyridinoline concentrations, have demonstrated that bone resorption is decreased in PEM. Thanks to the availability of new specific biochemical markers, such as osteocalcin, it was found relevant to reevalute with more insight the other side of bone turnover, i.e. bone formation.

Osteocalcin is the most abundant noncollagenous bone protein and is produced by osteoblast (3). Most of the newly synthesized osteocalcin remains bound to bone hydroxyapatite, but a small fraction of the protein is released into the blood (3, 4) and serum osteocalcin appears to be an useful marker of

Received September 30, 1994; accepted January 19, 1995.

Corresponding author and reprint requests: Daniel Lemonnier, INSERM-GERM, Faculté de Médecine Xavier Bichat, BP 416, 75870 Paris cédex 18, France. bone formation (4). To further clarify possible effects of PEM on bone formation, serum osteocalcin concentrations were determined in groups of children from Senegal (West Africa) with various forms of malnutrition in relation to markers of the protein energy and the inflammation status. In addition, the main regulators of osteocalcin synthesis, i.e. $1,25(\mathrm{OH}) 2 \mathrm{D}$ and parathyroid and thyroid hormones, were measured to investigate the regulation of serum osteocalcin concentration in PEM.

\section{METHODS}

Our criteria for inclusion in the study were based on age and anthropometric and clinical parameters. Because a seasonal rhythm was reported for the serum osteocalcin level (4), the duration of our study in the field did not exceed $1 \mathrm{mo}$. Fifty-two Senegalese children nine to 24 mo old were included in the study and classified according their clinical symptoms and their height-for-age in a $Z$ score, which represents the distance of a value above or below the median of NCHS-FELS growth charts (5), expressed in SD units adjusted for age and sex: seven $\mathrm{K}$ and $14 \mathrm{M}$ children, two severe forms of PEM, hospitalized in Dakar (Senegal) for nutritional rehabilitation; 
31 children attending the maternal and child health care center in Dakar were then divided into three groups, five SS with height-for-age $<-2 Z$ score, nine MS with height-for-age comprised between -1 and $-2 Z$ score, and $17 \mathrm{CD}$ with height-for-age $>-1 Z$ score. In addition, eight healthy agematched black African children, born and living in Paris (France) with height-for-age $>-1 \mathrm{Z}$ score, were included in the study as a further $\mathrm{CP}$. All children of the CP group received cholecalciferol supplementation of $0.3 \mathrm{mg} / \mathrm{d}$ before the age of $10 \mathrm{mo}$ and $5 \mathrm{mg} / 4 \mathrm{mo}$ between 10 and $24 \mathrm{mo}$. Thus, we have constituted six groups of children (CP, CD, MS, SS, M, and K), and their anthropometric data are summarized in Table 1. The hospital Le Dantec (Dakar, Senegal) did not have a special ethics committee, but the protocol of the study was approved by the authorities of the hospital, and ethical aspects of this study were in accordance with the letter and the spirit of the Helsinki Declaration II.

Blood samples were withdrawn from the nonfasting children between 0900 and $1200 \mathrm{~h}$ on admission to the hospital before any treatment was started. Blood samples were allowed to clot on ice about $1 \mathrm{~h}$ and then centrifuged at $4^{\circ} \mathrm{C}$, and the resulting serum was aliquoted and stored at $-20^{\circ} \mathrm{C}$ before analysis. Special attention was given to the temperature during blood collection in the hospital and transfer of the samples from Dakar to Paris ( $5 \mathrm{~h}$ by plane). All of the assays were performed during the month after the end of the field work, and all hemolyzed samples were excluded from the assays. Serum osteocalcin was determined by RIA (6) using an RIA kit (ORIS-CIS, Gif-sur-Yvette, France). The coefficients of variations within assay and between assays were, respectively, 3.0 and $5.5 \%$. The antiserum in the kit recognizes especially the carboxy-terminal end of the osteocalcin molecule, and it binds $50-60 \%$ of the amount of labeled osteocalcin. Serum transthyretin, a sensitive marker of protein-energy status, was measured by electroimmunoassay (7). $\alpha-1$ acid glycoprotein, an acute-phase reactant protein, was measured by radial immunodiffusion (7). In addition, for the most stunted children the following parameters were measured compared with CD children. Total and free triiodothyronine and total thyroxine were determined by using RIA kits (Kodak Diagnostics, Les Ulis, France). iPTH concentrations were measured using an RIA kit (Nichols Institute Diagnostics, San Juan Capistrano, CA). Serum $1,25(\mathrm{OH}) 2 \mathrm{D}$ and $25(\mathrm{OH}) \mathrm{D}$ were measured by competitive binding protein assay $(8,9)$.
Statistical analysis was performed using Systat computer program 5.01 (Evanston, IL). Differences between groups were determined using analysis of variance followed by Dunnett's pairwise comparisons test where appropriate. The relationships between serum osteocalcin concentration and other parameters were analyzed by Pearson's linear correlation test and multivariate regression analysis. A $p$ value less than 0.05 was considered significant, and results were expressed as mean \pm SEM.

\section{RESULTS}

Table 2 shows that serum osteocalcin concentrations were low $(-46 \%)$ in control children living in Dakar compared with those from Paris. Serum osteocalcin concentrations were even significantly lower in stunted (MS and SS) and in severely malnourished ( $\mathrm{M}$ and $\mathrm{K}$ ) groups compared with the $\mathrm{CD}$ group. Serum transthyretin concentrations were significantly decreased in hospitalized children ( $\mathrm{M}$ and $\mathrm{K}$ ). In contrast, serum $\alpha-1$ acid glycoprotein concentrations were significantly increased in hospitalized children ( $\mathrm{M}$ and $\mathrm{K}$ ) compared with the $\mathrm{CD}$ group.

In the $\mathrm{M}$ group, serum osteocalcin was correlated with weight for age $(r=-0.67, p<0.009, n=14)$ and height for age $(r=-0.54, p<0.047, n=14)$. However, multiple regression analysis shows that, when weight for age was held constant, serum osteocalcin was not correlated to height for age. Likewise, when considering only control children with weight for height and height for age above $-1 Z$ score (CD and $\mathrm{CP}$ ), serum osteocalcin was not correlated with anthropometric parameters.

Table 3 shows parameters determined in $\mathrm{M}$ and in $\mathrm{CD}$ children living in Dakar. Serum iPTH, 1,25(OH)2D, and $25(\mathrm{OH}) \mathrm{D}$ concentrations were not affected in the marasmic group compared with $\mathrm{CD}$ control group. In contrast thyroid hormones (total triiodothyronine, total thyroxine, and free triiodothyronine) concentrations were significantly decreased in the marasmic group.

When Pearson's correlation test was performed within any of the groups, and serum osteocalcin and transthyretin were correlated in the CD group $(r=0.58, p<0.015, n=17)$, and in the $\mathrm{M}$ group $(r=0.78, p<0.001, n=14)$. However, in the $\mathrm{M}$ group, multiple regression analysis shows that, when trans-

Table 1. Anthropometric parameters of the children

\begin{tabular}{|c|c|c|c|c|c|}
\hline \multirow[b]{2}{*}{ Children groups $(n)^{*}$} & \multirow[b]{2}{*}{$\begin{array}{c}\text { Sex ratio, } \\
\text { F/M }\end{array}$} & \multirow[b]{2}{*}{ Age $(\mathrm{mo})$} & \multicolumn{3}{|c|}{$Z$ score } \\
\hline & & & Height for age & Weight for age & $\begin{array}{c}\text { Weight for } \\
\text { height }\end{array}$ \\
\hline $\mathrm{CP}(8)$ & $1 / 7$ & $15.44 \pm 2.29$ & $0.01 \pm 0.14$ & $-0.16 \pm 0.26$ & $-0.12 \pm 0.30$ \\
\hline $\mathrm{CD}(17)$ & $7 / 10$ & $13.83 \pm 0.92$ & $0.77 \pm 0.19$ & $0.10 \pm 0.16$ & $-0.35 \pm 0.15$ \\
\hline MS (9) & $4 / 5$ & $18.86 \pm 1.14$ & $-1.39 \pm 0.08 \dagger$ & $-1.04 \pm 0.18 \dagger$ & $-0.34 \pm 0.23$ \\
\hline SS (5) & $1 / 4$ & $18.82 \pm 1.85$ & $-2.29 \pm 0.10 \dagger$ & $-1.07 \pm 0.28 \dagger$ & $0.34 \pm 0.40$ \\
\hline M (14) & $5 / 9$ & $15.89 \pm 1.31$ & $-2.57 \pm 0.34 \dagger$ & $-4.60 \pm 0.16 \dagger$ & $-4.02 \pm 0.17 \dagger$ \\
\hline $\mathrm{K}(7)$ & $3 / 4$ & $17.36 \pm 1.42$ & $-1.58 \pm 0.30 \dagger$ & $-3.03 \pm 0.23 \dagger$ & $-2.90 \pm 0.40 \dagger$ \\
\hline
\end{tabular}

* Children groups are: apparently healthy control living in Paris (CP) or in Dakar (CD), moderately stunted (MS) or severely stunted (SS), hospitalized for marasmus (M) or kwashiorkor (K). F and $\mathrm{M}$ represent respectively the numbers of female and male in each group. Values are mean \pm SEM.

$\dagger p<0.001$ vs the group $\mathrm{CD}$. 
Table 2. Serum osteocalcin, transthyretin, and $\alpha-1$ acid glycoprotein of the children

\begin{tabular}{lccc}
\multicolumn{4}{c}{ glycoprotein of the children } \\
\hline $\begin{array}{l}\text { Children } \\
\text { group }(n)^{*}\end{array}$ & $\begin{array}{c}\text { Osteocalcin } \\
(\mathrm{nmol} / \mathrm{L})\end{array}$ & $\begin{array}{c}\text { Transthyretin } \\
(\mu \mathrm{mol} / \mathrm{L})\end{array}$ & $\begin{array}{c}\alpha-1 \text { acid } \\
\text { glycoprotein } \\
(\mu \mathrm{mol} / \mathrm{L})\end{array}$ \\
\hline CP $(8)$ & $3.66 \pm 0.26 \dagger$ & $3.11 \pm 0.33$ & $19 \pm 2$ \\
$\mathrm{CD}(17)$ & $2.00 \pm 0.23$ & $2.51 \pm 0.16$ & $32 \pm 3$ \\
$\mathrm{MS}(9)$ & $1.20 \pm 0.16 \ddagger$ & $2.18 \pm 0.25$ & $43 \pm 7$ \\
$\mathrm{SS}(5)$ & $1.12 \pm 0.34 \ddagger$ & $1.93 \pm 0.34$ & $38 \pm 6$ \\
M (14) & $0.85 \pm 0.13 \dagger$ & $1.64 \pm 0.18 \S$ & $52 \pm 5 \S$ \\
$\mathrm{K}(7)$ & $0.22 \pm 0.04 \dagger$ & $0.93 \pm 0.16 \dagger$ & $76 \pm 9 \dagger$ \\
\hline
\end{tabular}

* Children groups are: apparently healthy control living in Paris (CP) or in Dakar (CD), moderately stunted (MS) or severely stunted (SS), hospitalized for marasmus $(\mathrm{M})$ or kwashiorkor $(\mathrm{K})$. Values are means \pm SEM.

$\dagger p<0.001$ vs the group $\mathrm{CD}$.

$\ddagger p<0.05$.

$\S p<0.01$.

thyretin was held constant, the correlation between osteocalcin and weight for age became insignificant.

\section{DISCUSSION}

This study shows that serum osteocalcin concentrations were dramatically reduced in children suffering from severe malnutrition. These results are in accordance with previous findings of depressed bone formation in PEM (10). Thus, taking into account the reduction of bone resorption in Jamaican malnourished children (2), it is suggested that osteopenia in PEM may be of low bone turnover type, with coupled bone formation and resorption.

Recently, the Delmas's team (11) using a battery of MAb have characterized the various immunoreactive forms of circulating osteocalcin in normal adult serum. The intact 49amino acid molecule represents only $36 \%$ of the total immunoreactivity, and the remaining $64 \%$ are constituted by osteocalcin fragments. But interestingly this pattern of fragment distribution is similar in both osteoporotic and pagetic patients, suggesting that the fragmentation results from serum enzymatic degradation, rather than from being released from bone matrix during resorption $(12,13)$. However, we do not know to what extent the osteocalcin resorbed from the bone matrix could contribute to the reduced circulating levels of osteocalcin in malnutrition. It is widely acknowledged that serum osteocalcin is increased in case of renal failure (14),

Table 3. Comparison of biochemical parameters between control and marasmic groups

\begin{tabular}{lcc}
\hline \multicolumn{1}{c}{$\begin{array}{c}\text { Biochemical } \\
\text { parameters* }\end{array}$} & $\begin{array}{c}\text { Control }(\mathrm{CD}) \\
(n=17)\end{array}$ & $\begin{array}{c}\text { Marasmic } \\
(\mathrm{M})(n=14)\end{array}$ \\
\hline $1,25(\mathrm{OH})_{2} \mathrm{D}(\mathrm{pmol} / \mathrm{L})$ & $92 \pm 6$ & $96 \pm 11$ \\
$25(\mathrm{OH}) \mathrm{D}(\mathrm{nmol} / \mathrm{L})$ & $64 \pm 4$ & $73 \pm 8$ \\
$\mathrm{iPTH}(\mathrm{pmol} / \mathrm{L})$ & $2.80 \pm 0.35$ & $2.90 \pm 0.36$ \\
$\mathrm{~T} 3 \mathrm{nTmol} / \mathrm{L})$ & $2.31 \pm 0.40$ & $0.83 \pm 0.20 \dagger$ \\
FT3 $(\mathrm{pmol} / \mathrm{L})$ & $6.46 \pm 0.86$ & $2.71 \pm 0.51 \dagger$ \\
T4T $(\mathrm{nmol} / \mathrm{L})$ & $127 \pm 14$ & $72 \pm 7 \dagger$ \\
\hline
\end{tabular}

* Biochemical parameters $1,25(\mathrm{OH})_{2} \mathrm{D}$ is 1,25 -dihydroxycholecalciferol, 25(OH)D is 25-hydroxycholecalciferol, iPTH is parathyroid hormone, T3T and FT3 are total and free triiodothyronine, T4T is total thyroxine. Values are mean \pm SEM.

$\dagger p<0.01$. therefore the low serum osteocalcin is not attributable to the reduction of the GFR that is found during malnutrition (15).

The low serum osteocalcin levels in stunted children are also in accordance with previous findings (16). However, although both the control groups have the same anthropometric values, the serum osteøcalcin levels were $46 \%$ lower in Dakar compared with Páris. These data do not support a direct relationship between growth and serum osteocalcin levels. It is noteworthy that serum osteocalcin values observed in black African children living in Paris (CP) were similar to those of normal French children (16). The difference in osteocalcin concentration observed between control children living in Paris and Dakar may be a seasonal effect, i.e. the influence of sunlight (17). But it is difficult to take into account the possible seasonal effect on the osteocalcin level inasmuch as 1 ) it is not only related to the influence of sunlight, but to the sun exposure habits; 2) there is seasonal variation in France, but this is not the case in Senegal; and 3) conflicting data have been published about the seasonal rhythm of serum osteocalcin (17). However, a frequent finding in the literature is that serum osteocalcin is low in black subjects (18). In a recent study, Perry et al. (19) have found also a concomitant low serum albumin and normal 25(OH)D concentrations in older AfricanAmericans, suggesting a poor protein-energy status that could be related to their low serum osteocalcin. It is known that serum osteocalcin is lower in female than in male subjects $(17$, 20 ). The higher proportion of female subjects in the CD group than in the CP group could contribute to the decrease of the mean serum osteocalcin level found in the CD group. However, when considering only the male subjects, their serum osteocalcin level mean value was $3.74 \pm 0.30 \mathrm{nmol} / \mathrm{L}$ in the $\mathrm{CP}$ group and $2.09 \pm 0.23 \mathrm{nmol} / \mathrm{L}$ in the $\mathrm{CD}$ group. Furthermore, in the CD group, serum osteocalcin concentrations of girls were no different from those of boys $(1.87 \pm 0.49 \mathrm{nmol} / \mathrm{L}$ versus $2.09 \pm 0.23 \mathrm{nmol} / \mathrm{L}$ ). Then, these results suggest that the low serum osteocalcin concentrations found in Dakar's children were not related to a racial factor or sex distribution but could be related to environmental constraints.

At least the high prevalence of infections and poor nutritional intakes in this area might be involved in the observed low levels of serum osteocalcin. Indeed, when considering the threshold of $30 \mu \mathrm{mol} / \mathrm{L}$ for $\alpha-1$ acid glycoprotein, it is noteworthy that most of the children living in Dakar were seen to be inflamed and/or infected. However, a comparison between eight infected and nine noninfected children of the $\mathrm{CD}$ group did not show any difference in serum osteocalcin $(1.94 \pm 0.42$ versus $2.06 \pm 0.26 \mathrm{nmol} / \mathrm{L}$, respectively). These results are in accordance with our previous finding showing that, in rats, serum osteocalcin is not affected by experimental inflammation (21). Therefore, these studies suggest that the low serum osteocalcin concentrations found in malnourished children were independent of inflammatory status.

In $\mathrm{M}$ and $\mathrm{K}$, serum osteocalcin and transthyretin levels were deeply decreased on admission to the hospital. In $\mathrm{K}, 3 \mathrm{wk}$ of nutritional rehabilitation produced a significant rise in both of these proteins (6), suggesting that serum osteocalcin level is sensitive to nutritional status. This is strengthened by the low osteocalcin levels found in patients suffering from anorexia 
nervosa (22), in 3-day starved rats (21), or after 4 wk of dietary restriction in rats (23), whereas high osteocalcin levels are found in obese children fed an energy-rich diet (24). Michaelsen et al. (25) have found a positive correlation between serum osteocalcin and milk intake in a study of 2- to 9-mo-old breast-fed babies. Serum osteocalcin levels were raised in these breast-fed babies compared with age-matched formula-fed babies (25). In Senegal, a recent national demographic and health surveys (26) have shown that $98 \%$ of babies are breast-fed at $9 \mathrm{mo}, 85.3 \%$ are breast fed at $17 \mathrm{mo}$, but only $38.5 \%$ still breast fed at $24 \mathrm{mo}$. The mean duration of breastfeeding is $20.1 \mathrm{mo}$ in Senegal. Considering these results and the fact that the mean ages of our different groups of children are not so different, the decrease of serum osteocalcin in MS, $\mathrm{SS}, \mathrm{M}$, and $\mathrm{K}$ groups cannot be ascribed to the pratice of breast feeding. Furthermore, the findings of Michaelsen et al. (25) are not in accordance with our study, because when considering that serum osteocalcin levels decreased with age and assuming that breast-feeding is more frequent in Dakar than Paris, we found that serum osteocalcin levels are lower in the CD group (mean age $=13.83 \pm 0.92 \mathrm{mo}$ ) compared with the CP group (mean age $=15.44 \pm 2.29 \mathrm{mo}$ ). In our study, it is difficult to distinguish the effects of breast-feeding and age on serum osteocalcin, therefore the effect of breast-feeding on serum osteocalcin needs to be further investigated.

There was no vitamin D deficiency in marasmic and control children living in Dakar, as showed by high levels of serum $25(\mathrm{OH}) \mathrm{D}$, the storage form of vitamin D. Likewise, serum $1,25(\mathrm{OH}) 2 \mathrm{D}$, the active metabolite of vitamin $\mathrm{D}$, was no different in marasmic children compared with control children living in Dakar, suggesting that their very low serum osteocalcin levels were not attributable to levels of serum 1,25(OH)2D. Indeed, we have found in 3-day starved rats a significant decrease in serum osteocalcin without any change in the concentration of serum 1,25(OH)2D (21). Serum iPTH, another potential regulator of osteocalcin production (27), cannot explain a low serum osteocalcin level in PEM, because iPTH concentrations were similar in marasmic and CD control groups. In contrast, thyroid hormone concentrations, which were significantly decreased in marasmic children, could be involved in the decrease of serum osteocalcin. Indeed, hyperthyroidism is often associated with elevated serum osteocalcin levels, whereas low serum osteocalcin levels are found in hypothyroidism (28). Furthermore, in vivo or in vitro studies have disclosed an increase in osteocalcin synthesis after treatment with physiologic amounts of thyroid hormones $(29,30)$. However, osteocalcin synthesis may be decreased by other unmeasured factors, such as low insulin-like growth factor I (31) and high cortisol levels (32), that are frequently found in malnourished children (33). Cortisol levels that were higher in $\mathrm{K}$ than $\mathrm{M}$ (34) may explain the lowest osteocalcin levels found in kwashiorkor. However, there are conflicting data in the literature. Vashi and Jagatiani (35) found no difference in serum cortisol levels between marasmus and kwashiorkor, whereas others $(36,37)$ found that the cortisol level is more elevated in marasmus than kwashiorkor. Thus, the lowest serum osteocalcin levels found in $\mathrm{K}$ remain unclear.
In summary, very low levels of serum osteocalcin were found in stunted and malnourished Senegalese children. The data suggest that serum osteocalcin is related to protein-energy status assessed by serum transthyretin. This is in accordance with previous data obtained in food-restricted rats. The low levels of serum osteocalcin observed in control children living in Dakar suggest that they were not in optimal nutritional status (7) and that bone formation could be altered not only in the malnourished but also in those considered as anthropometrically normal. We suggest that serum osteocalcin could be a new useful tool in the study of bone formation during malnutrition. The serum osteocalcin concentration is widely used in many different clinical settings, including those involving bone, kidney, and liver diseases. It is suggested that these studies should include an assessment of the nutritional status before interpreting the changes in serum osteocalcin concentration.

Acknowledgments. The authors thank the staff of the Département de Pédiatrie, Hôpital A. LeDantec, Dakar (Sénégal), Institut de Pédiatrie Sociale, Pikine (Sénégal), and the Centre des bilans de santé l'enfant, Rue Amelot, Paris (France) for help in subject recruitment.

\section{REFERENCES}

1. Garn SM, Kangas J 1980 Protein intake, bone mass, and bone loss. In: DeLuca HF, Frost HM, Jee WS, Johnston CC, Parfitt AM (eds) Osteoporosis: Recent Advances in Pathogenesis and Treatment. University Park Press, Baltimore, pp 257-263

2. Branca F, Robins SP, Ferro-Luzzi A, Golden MHN 1992 Bone turnover in malnourished children. Lancet 340:1493-1496

3. Gehron RP 1989 The biochemistry of bone. Endocrinol Metab Clin North Am 18:859-902

4. Delmas PD 1990 Biochemical markers of bone turnover for the clinical assessment of metabolic bone disease. Endocrinol Metab Clin North Am 19:1-18

5. World Health Organisation 1983 Measuring change in nutritional status. WHO, Geneva

6. Prudhon C, Sall G, NDiaye B, Lemonnier D 1991 Régulation nutritionnelle de l'ostéocalcine sérique: étude dans le kwashiorkor. CR Acad Sci (Paris) 313:233-238

7. Wade S, Parent G, Bleiberg-Daniel F, Maire B, Fall M, Schneider D, LeMoullac B, Dardenne M 1988. Thymulin (Zn-FTS) activity in protein-energy malnutrition: new evidence for interaction between malnutrition and infection on thymic function. Am J Clin Nutr 47:305-311

8. Wilhelm F, Norman AW 1984 Cooperativity in the binding of $1 \alpha, 25$ dihydroxivitamin D3 to chick intestinal resceptor. FEBS Let 170:239-242

9. Zeghoud F, Jardel A, Guillozo H, N'Guyen TM, Garabedian M 199125 Hydroxyvitamine $\mathrm{D}$ : mise au point d'un microdosage par radiocompétition. Intérêt en pédiatrie. Immunoanal Biol Spec 27:29-33

10. Himes JH 1978 Bone growth and development in protein-calorie malnutrition. World Rev Nutr Diet 28:143-187

11. Delmas PD 1993 Biochemical markers of bone turnover. I. Theoretical considerations and clinical use in osteoporosis. Am J Med 95(suppl 5A): 11S-16S

12. Garnero P, Gimaux M, Demiaux B, Preaudat C, Seguin P, Delmas PD 1992 Measurement of serum osteocalcin with human-specific two-site immunoradiometric assay. J Bone Miner Res 12:1389-1398

13. Garnero P, Gimaux M, Borel O, Seguin P, Delmas PD 1992 Immunoreactive forms of circulating human osteocalcin. J Bone Miner Res 7: S155

14. Delmas PD, Wilson DM, Mann KG, Riggs BL 1983 Effect of renal function on plasma levels of bone gla-protein. J Clin Endocrinol Metab 57:1028-1030

15. Gordillo-Paniagua G, Frenk S 1990 Renal function in the malnourished child. In: Suskind RM, Lewinter-Suskind L (eds) The Malnourished Child. Nestlé Nutrition Workshop Series, Vol. 19. Nestec Ltd., Vevey/Raven Press, Ltd., NY, pp 309-328

16. Colle M, Ruffie A, Ruedas E 1988 Osteocalcin in children with short stature. Acta Paediatr Scand Suppl 343:196-197

17. Power MJ, Fottrell PF 1991 Osteocalcin: diagnostic methods and clinical applications. Crit Rev Clin Lab Sci 28:287:335

18. Bell NH, Greene A, Epstein S, Oexmann MJ, Shaw S, Shary J 1985 Evidence for alteration of the vitamin D-endocrine system in blacks. J Clin Invest 76:470-473

19. Perry HM III, Miller DK, Morley JE, Horowitz MH, Kaiser FE, Perry HM Jr, Jensen J, Bentley J, Boyd S, Kraenzle D 1993 A preliminary report of vitamin D and calcium metabolism in older African Americans. J Am Geriatr Soc 41:612-616

20. Epstein S, McClintock R, Bryce G, Poser J, Johnston CC Jr, Hui S 1984 Differences in serum bone Gla protein with age and sex. Lancet 1:307-310 
21. NDiaye B, Prudhon C, Guillozo H, Lemonnier D 1992 Rat serum osteocalcin concentration is determined by food intake and not by inflammation. J Nutr 122:1870-1874

22. Fonseca VA, D'Souza V, Houlder S, Wakeling A, Dandona P 1988 Vitamin D deficiency and low osteocalcin concentrations in anorexia nervosa. J Clin Pathol 41:195-197

23. Ndiaye B, Pelissier MA, Lemonnier D 1993 Serum osteocalcin concentrations in protein and/or energy restricted rats. Nutr Res 13:71-76

24. Zamboni G, Soffiati M, Giavarina D, Tato L 1988 Mineral metabolism in obese children. Acta Paediatr Scand 77:741-746

25. Michaelsen KF, Johansen JS, Samuelson G, Price PA, Christiansen C 1992 Serum bone $\gamma$-carboxyglutamic acid protein in a longitudinal study of infants: lower values in formula-fed infants. Pediatr Res 31:401-405

26. Ndiaye S, Diouf PD, Ayad M 1994 Enquête démographique et de santé au Sénégal (EDS-II) 1992/93. Direction de la Prévision et de la Statistique, Dakar, Sénégal and Macro International Inc., Calverton, MD

27. Noda M, Yoon K, Rodan GA 1988 Cyclic AMP-mediated stabilization of osteocalcin mRNA in rat osteoblast-like cells treated with parathyroid hormone. J Biol Chem 263:18574-18577

28. Faber J, Perrild H, Johansen JS 1991 Serum bone gla protein (BGP) during treatment of hyperthyroidism and hypothyroidism. A longitudinal study. Horm Metab Res 23:135-138
29. Perry HM III 1989 Thyroid hormones and mineral metabolism. In: Peck WA (ed) Bone and Mineral Research No. 6, Elsevier Science Publishers B. V, Amsterdam, The Netherlands, pp 113-137

30. Ross DS, Graichen R 1991 Increased rat femur osteocalcin mRNA concentrations following in vivo administration of thyroid hormone. J Endocrinol Invest 14:763-766

31. Fournier B, Ferralli JM, Price PA, Schlaeppi JM 1993 Comparison of the effects of insulin-like growth factors-I and -II on the human osteosarcoma cell line OHS-4. J Endocrinol 136:173-180

32. Iwasaki T 1991 Effect of glucocorticoids on bone gla protein values (BGP) as a good marker of osteoporosis. Acta Paediatr Jpn 33:310-316

33. Waterlow JC 1992 Endocrine changes in severe PEM. In: Waterlow JC (ed) ProteinEnergy Malnutrition. Edward Anorld, London, pp 112-125

34. Tuchinda C, Chatranon W 1982 Blood cortisol levels in malnourished Thai children with and without acute stress. J Med Assoc Thailand 65:82-85

35. Vashi N, Jagatiani N 1980 Plasma cortisol and relation to malnutrition. Indian Pediatr 17:59-63

36. Rao KSJ, Srikantia SG, Gopalan C 1968 Plasma cortisol levels in protein-calorie malnutrition. Arch Dis Child 43:365-367

37. Misra PK, Agrawal CG, Prakash B, Bajpai PC 1980 Plasma cortisol, immunoreactive insulin and oral glucose tolerance in protein calorie malnutrition. Indian Pediatr $17: 411-415$ 